\title{
Obnażyć rzeczywistość \\ Nagość i erotyka w kinie polskim czasów przełomu
}

\author{
KAROL JACHYMEK
}

Kino nasze specjalizuje się $w$,, seksie rozpaczliwym”. Można na poczekaniu wybrać caty katalog scen, które pod względem drastyczności nie maja sobie podobnych w kinie światowym, tyle w nich wstydu, zażenowania, smutku (...). Kiedy natomiast polski reżyser pragnie wyzwolić się z poczucia winy, popada $w$ styl „przyszła baba do lekarza”. Nic pośredniego. Luka w kulturze ${ }^{1}$ - argumentował Tadeusz Sobolewski w recenzji filmu Porno (1989) Marka Koterskiego. Ta uwaga, mimo że po części przesadzona, stanowi trafny punkt wyjścia do rozważań na temat roli nagości i erotyki w kinie polskim czasów przełomu. Nie chodzi nawet o zawartą $\mathrm{w}$ tych słowach diagnozę dotyczącą dychotomicznej niejako obecności dwóch najczęściej pojawiających się kategorii scen erotycznych, które z reguły można było obejrzeć w realizowanych ówcześnie filmach (choć trzeba oczywiście zaznaczyć, że skala filmowych przedstawień erotycznych była wówczas mimo wszystko zdecydowanie bardziej stopniowalna). Przywołana wypowiedź krytyka świadczy przede wszystkim o nie do końca jednorodnym, acz na pewno znaczącym miejscu, jakie szeroko definiowana tematyka erotyczna zajmowała nie tylko w twórczości filmowej, ale też kulturze polskiej omawianego okresu. Mimo że erotyka była coraz częściej obecna (nie tylko) na ekranach ówczesnych kin, nieustająco spotykała się w Polsce ze spolaryzowanym oddźwiękiem. Sytuacja ta w istocie wiele mówi o specyfice transformacji i zachodzących wtedy w naszym kraju przemianach obyczajowych.

Owa ambiwalencja w mówieniu o erotyce nie jest oczywiście charakterystyczna wyłącznie dla przełomu lat 80. i 90. To stan typowy w gruncie rzeczy dla rodzimej rzeczywistości społeczno-kulturowej. W 1967 r. Andrzej Banach w tekście Erotyzm po polsku pośród różnych czynników, które miałyby jego zdaniem wpłynąć na mglistą sytuację erotyki w kulturze polskiej, wymienił zatem m.in. nieprzyjazny klimat, ciężkostrawną dietę, podejście do higieny, wpływy religii, naszą historię i (trudną) przeszłość, stosunek do kobiet, a także doskwierający wręcz brak tradycji w zakresie sztuki erotycznej ${ }^{2}$. Mimo że refleksje z lat 60 . mogą wydać się współcześnie dosyć anachroniczne, a niektóre z nich z dzisiejszej perspektywy jawią się wręcz jako co najmniej zabawne, to mimo wszystko w dalszym ciągu mogą stanowić cenną informację na temat okoliczności, w jakich ukonstytuowało się polskie podejście do nagości i erotyki. Religia, historia, trud, wstyd, grzech, nieobecność, brak, ukrycie, liczne przeciwności losu... Niewątpliwie wszystkie te przesłanki musiały w mniejszym lub większym stopniu wpłynąć na pogmatwane miejsce, jakie zajmowała i, co ważne, w dalszym ciągu zajmuje erotyka w naszej kulturze. Jak bowiem przekonywał Andrzej Banach: Pomiędzy powinnościa spłodzenia potomstwa dla ojczyzny i zachowania włości - i pomiędzy ogniem piekielnym z drugiej 
strony, leżat kraj tajemniczy: konieczny i zakazany, przyjemny i straszny, osobisty $i$ wszystkim wspólny, za każdym razem całkiem nowy i za każdym razem taki sam. To byt erotyzm. O jego treści i kształcie decydowało to, co było z lewej strony i z prawej strony: zakazy i próby usprawiedliwienia, czynniki ujemne i dodatnie, hamujace i upiększające. (...) Co prawda, sam wąsacz z obrazka należy już do muzeum. Ale nie wszystkie warunki, które go wytworzyly ${ }^{3}$.

Warto w tym miejscu nadmienić, że słowa „nagość” i „erotyka”, przywołane przeze mnie już w samym tytule, to oczywiście pojęcia bynajmniej nie synonimiczne. Erotyzm, zgodnie z definicją zaproponowaną przez Zbigniewa Lwa-Starowicza, w pewnym uproszczeniu oznaczałby zatem zainteresowanie i odczuwanie przyjemności wiążacych się z atrakcyjnościa fizyczna i psychiczna osób w relacjach hetero- czy homoseksualnych ${ }^{4}$. Tym samym, jako cecha charakterystyczna wyłącznie dla człowieka, nadawałby on jego seksualności ponadbiologiczna i ponadprokreacyjna wartość 5, obejmując równocześnie biologiczny, psychiczny, społeczny $i$ kulturowy wymiar ${ }^{6}$ jego egzystencji. Erotyka rozumiana jako twórczość erotyczna byłaby natomiast przejawem „ekspresji erotycznej”, czyli konkretnie tego wymiaru wielopłaszczyznowego w swojej istocie zjawiska erotyzmu, który świadczyłby przede wszystkim o społeczno-kulturowych, specyficznie ludzkich formach jego przeżywania ${ }^{7}$. Nagość zaś, jakkolwiek banalnie to zabrzmi, to w gruncie rzeczy stan związany po prostu z nieposiadaniem (na sobie) ubrania, z jego (niekiedy znaczącym) brakiem. Choć często może implikować wiele kulturowych sensów, nie musi być przecież w żadnym razie erotyczna.

W kinie i kulturze polskiej czasów transformacji status nagości i erotyki był jednak zdecydowanie bardziej złożony. Niekiedy nawet obydwie te kategorie funkcjonowały jako w pewnym stopniu tożsame, często wywołując w odbiorcach zupełnie zbliżone reakcje. Świadczyć o tym może chociażby słynna anegdota, którą w artykule Seks po polsku przywołał Stanisław Kuszewski. Rzecz dotyczy mało skądinąd erotycznego filmu Bez końca (1984) w reżyserii Krzysztofa Kieślowskiego: po zakończeniu sceny, w której bohaterka (Szapołowska) oddaje się w hotelu cudzoziemcowi dewizowemu, młody człowiek z i tak już niezbyt licznej widowni głośno przedstawił koledze propozycję nie do odrzucenia - „Pójdziem, Kaziu, już się więcej p... nie będa”. Na takie dictum wytrawnego widać kinomana spora grupa młodych ludzi, trzaskając fotelami, podniosła się z miejsc i zdecydowanie skierowała się ku wyjściu, uznawszy, że nie może już liczyć na dalsze zaspokajanie przez ów film swoich potrzeb estetycznych ${ }^{8}$. Dość powiedzieć, że ta historyjka, mimo iż opowiada o pierwszej połowie lat 80., doskonale ujawnia wieloznaczność, a nawet swego rodzaju wielopoziomowość ówczesnych kodów kulturowych związanych z tym-co-potencjalnie-erotyczne. Z jednej strony słychać w niej bowiem wyraźną krytykę dotyczącą niezbyt wyrafinowanego zachowania widzów, z drugiej natomiast mówi ona wiele na temat autentycznych potrzeb samej publiczności, zainteresowanej oglądaniem filmów poruszających tego typu tematykę. Owa dychotomia zupełnie jednak nie dziwi. Takie właśnie mieszanie się, a może nawet - ścieranie się przeciwstawnych niekiedy porządków, czego ślad nietrudno dostrzec również w zacytowanej przed momentem wypowiedzi, było wszak niezwykle charakterystyczne dla ówczesnej rzeczywistości społeczno-kulturowej. W szeroko definiowanym świecie przełomu nagość i erotyka bez dwóch zdań stanowiły bowiem szczególnie istotny punkt odniesienia. 


\section{Przelom}

Czasy transformacji ustrojowej to w istocie moment dynamicznego i karnawałowego wręcz, by nawiązać do tytułu książki Beaty Łaciak ${ }^{9}$, przenikania się różnorakich hierarchii. W tym sensie przełom ten trudno uznać za zjawisko jednorodne, przejrzyście usystematyzowane czy mające precyzyjnie skodyfikowaną strukturę. Pojęcie to, w moim rozumieniu, nie odnosi się wyłącznie do bezpośredniej cezury 1989 r. i do realiów zachodzących wtedy wielkich przemian historycznych, politycznych i gospodarczych. Wiązałoby się raczej z ciągiem różnych, niedużych, rozproszonych i symultanicznych procesów kulturowo-społecznych, będących, z jednej strony, skutkiem, z drugiej - zapowiedzią wzajemnego przenikania i mieszania się różnorakich zjawisk charakterystycznych zarówno dla „starej”, jak i „nowej” rzeczywistości ustrojowej ${ }^{10}$. Dla historyków kultury oraz badaczy przemian polskiego społeczeństwa lat 90. cezura roku 1989 jest pomocnym punktem odniesienia, ale czasem także kłopotliwym obciążeniem ${ }^{11}$. pisała Magda Szcześniak w książce Normy widzialności. Tożsamość w czasach transformacji. I dalej: Podręcznikowe narracje historyczne przedstawiaja rok 1989, a zwłaszcza jego pierwsza połowe, jako moment przełomu - zmiany systemu politycznego z komunistycznego na demokratyczny, a gospodarczego z gospodarki planowej na wolnorynkowa. Im bliżej przygladamy się jednak szczegółowym i rozproszonym mechanizmom kulturowym, ekonomicznym i politycznym, tym wyraźniej dostrzegamy, że wiele procesów - zarówno tych wdrażanych odgórnie, jak i podejmowanych oddolnie - rozpoczęło się co najmniej kilkanaście miesięcy przed rokiem przełomu, a inne zaś jeszcze wcześniej ${ }^{12}$.

Podobną trudność napotkamy, kiedy będziemy się starali wyznaczyć precyzyjny koniec transformacji. Co bowiem mogłoby być jego świadectwem lub emanacją? Czy transformacja skończyła się, kiedy nasze zachowania z przełomu lat 80. i 90. zaczęty wydawać się ,obciachowe”? Czy może wówczas, gdy na , szalone” lata 90. zaczęliśmy patrzeć z nostalgią? ${ }^{13}$ Odpowiedź na tak postawione pytania nie jest bynajmniej prosta ani szczególnie jednoznaczna. Nie wspominając już nawet o tym, że tego rodzaju rozważania arbitralnie zakładają, iż w kontekście transformacji w ogóle można mówić o jakimkolwiek jej zakończeniu - skoro może proces ten się nie zakończył? W tej na pierwszy rzut oka zaskakującej refleksji nie chodziłoby jednak o to, jak argumentowała Magda Szcześniak, że transformacja nie spowodowała przemian gospodarczych, kulturowych i spolecznych $w$ Polsce lat 80., 90. i 2000, ale o to, że być może od samego początku, opierając się $w$ dużej mierze na naśladownictwie i próbując idealnie powtórzyć zachodnia droge postęu, dokonać się nie mogła ${ }^{14}$.

O ile jednak nie uda nam się definitywnie rozstrzygnąć powyższych wątpliwości, o tyle na pewno należy zgodzić się z jedną kwestią - wspomniana ,zachodniość" procesów transformacyjnych jest zupełnie bezsporna. Swoją drogą często miały one wręcz charakter imitacyjny, czego przykładem może być rodzima recepcja serialu Dynastia (reż. Irving J. Moore i inni, 1981-1989), który był postrzegany w naszym kraju jako niemal wierne odbicie zachodniego kapitalizmu, rozbudzając tym samym nasze wyobrażenia dotyczące innej (nowej) rzeczywistości ustrojowej ${ }^{15}$. Marek Krajewski sugerował nawet, że jednym z kluczowych czynników niejako wspierających zachodzącą wtedy przemianę ustrojową była tzw. rewolucja wyobraźni. Proces ten wiązał się przede wszystkim z coraz większą 
dostępnością w naszym kraju szeroko rozumianych zachodnich treści, jak chociażby tekstów kultury popularnej, które coraz silniej zaczynały wpływać na świadomość Polaków, w rezultacie radykalnie ją transformując. Owa rewolucja wyobraźni, trwająca w Polsce na przełomie lat 80. i 90., mogła mieć miejsce przede wszystkim dzięki nowoczesnym środkom komunikowania, a zwłaszcza magnetowidom i antenom satelitarnym, które stały się wówczas niezwykle ważnym medium podpięcia pod globalne systemy produkcji i upowszechniania ${ }^{16}$. Jak przekonywał badacz, to one właśnie, a nie (...) prasa i zachodnie stacje radiowe, były odpowiedzialne za wypetnienie wyobraźni Polaków nowymi typami reprezentacji. Reprezentacji, których odmienność od socjalistycznej rzeczywistości popychała do zmiany ${ }^{17}$.

Dość powiedzieć, że wskutek tego procesu rodzima rzeczywistość medialna drugiej połowy lat 80 . została wypełniona m.in. kasetami wideo $z$ Conanami, Rambo, ,Lodami na patyku” i bawarskimi filmami pornograficznymi, a na ekranach telewizorów pojawity się Sabrina, C.C. Catch, Modern Talking, gwiazdy italo disco, breakdance i aerobic, a przede wszystkim reprezentacje zwyktego życia ludzi zachodniego świata, ludzi z problemami tak odmiennymi od tych, które byly udziatem Polaków ${ }^{18}$. Rozszalała wręcz obecność tego typu „obrazów stamtąd ”, jak trafnie scharakteryzował je Marek Krajewski, w naszej przestrzeni wizualnej w konsekwencji doprowadziła też do przekształcenia oferty rodzimych mediów. W kinach pojawity się filmy zawierajace odważne sceny erotyczne (,, Tabu”, , Łuk Erosa”, , Widziadło”, „Medium”), a telewizja próbowała konkurować z magnetowidami i telewizją satelitarna pierwsza polska opera mydlana (,, W labiryncie”), wieczornymi seansami softporno (,Różowa seria”) oraz programami prezentujacymi zachodnie teledyski (, Jarmark”) ${ }^{19}$. Co jednak szczególnie ważne, wszystkie te nowe doświadczenia medialne, niespotykane dotąd w Polsce w aż tak ogromnym natężeniu, nie tylko (...) przebudowywaty gusta Polaków okréslajace, co jest dobra rozrywka, muzyka, filmem, ale również zarażały wyobraźnię, produkując nowe standardy normalności zwiąane z ubiorem, fryzurami, wygladem mieszkań, pojazdów, relacji międzyludzkich i to one właśnie sprawiały, iż jak nigdy przedtem luka pomiędzy tym, jak jest, a być może stawała się wyraźna, obiektywna i percypowalna ${ }^{20}$.

\section{O porno-chic}

Jednym z „obrazów stamtąd”, który z coraz większą śmiałością zaczął wówczas przenikać do polskiej rzeczywistości medialnej, była oczywiście również szeroko definiowana tematyka erotyczna. Przełom lat 80. i 90. to bowiem okres wyraźnej erotyzacji, a nawet pornografizacji zachodniej kultury popularnej, w piśmiennictwie określony mianem tzw. drugiej fali porno-chic ${ }^{21}$. Wcześniejsza fala tego zjawiska miała miejsce na początku lat 70. i można ją połączyć z trwającą wtedy w USA rewolucją obyczajową. Moment ten, nazywany także The Golden Age of Porn, wiązał się jednak przede wszystkim z dostrzeżeniem transgresyjnego potencjału pornografii. Oznacza to mniej więcej tyle, że treści jednoznacznie pornograficzne wkroczyły wówczas do kultury głównego nurtu, a ich świadoma konsumpcja stała się przejawem nowoczesnych, liberalnych postaw (amerykańskiego) społeczeństwa. W rezultacie doprowadziło to do tego, że na ekranach kin szeroka widownia zachodnia mogła obejrzeć chociażby takie filmy pornograficzne, jak: 
Mona. The Virgin Nymph (reż. Michael Benveniste, Howard Ziehm, 1970), Boys in the Sand (reż. Wakefield Poole, 1971), The Devil in Miss Jones (reż. Gerard Damiano, 1973) czy - zwłaszcza - Głębokie gardło (Deep Throat, reż. Gerard Damiano, 1972). Należy jednak pamiętać, że ich masowa lektura wynikała nie tylko na przykład z chęci zaspokojenia ciekawości osób niezaznajomionych dotąd z pornografią, ale była także świadectwem postaw kontrkulturowych ${ }^{22}$.

Porno-chic drugiej fali, jak przekonywał Brian McNair, nie jest natomiast pornografia, lecz wizerunkiem pornografii w niepornograficznej sztuce i kulturze, jest pastiszem i parodia, hołdem złożonym pornografii i jej badaniem. Stanowi postmodernistyczne przeksztatcenie porno $w$ artefakt kultury większości, majacy (...) różne zastosowania, łącznie z reklama, sztuka, komedia i edukacją ${ }^{23}$. Jego głównym zadaniem było bowiem przede wszystkim przeniesienie transgresyjnych cech pornografii i dotyczacych jej tabu na teren produkcji kulturalnej skierowanej do szerokiego odbiorcy ${ }^{24}$. Z tego właśnie powodu za jedną z najważniejszych ikon analizowanego zjawiska uznaje się Madonnę. Wizerunek, po jaki sięgnęła chociażby przy okazji premiery albumu Erotica (1992) i książki Sex (1992), nawiązujący m.in. do estetyki i kultury BDSM, miał być przecież zaangażowanym komentarzem na temat (represjonowanej) kobiecej seksualności. Choć należy przy tym podkreślić, że porno-chic przełomu lat 80 . i 90 . nie pojawiał się oczywiście wyłącznie w tego typu reprezentacjach. O wyraźnej pornografizacji ówczesnej kultury popularnej, i to w równie silny sposób, świadczyłaby bowiem także m.in. medialna obecność Pameli Anderson, Sabriny, Samanthy Fox czy wywodzącej się z naszego kraju Danuty Lato ${ }^{25}$. To głównie w takim właśnie, by tak rzec nadeksponowanym charakterze druga fala porno-chic wkroczyła również do Polski ${ }^{26}$ (co swoją drogą mówi wiele na temat specyfiki transformacji i zachodzących wtedy przemian).

\section{Rozebrać kino}

Słowo „wkroczyła” wydaje się zresztą w tym kontekście jak najbardziej uzasadnione. W drugiej połowie lat 80 . wyobraźnię Polaków zaludniać bowiem zaczęły z wielkim impetem coraz bardziej erotyczne, a nawet pornograficzne treści, docierające do naszego kraju z Zachodu. Ogromną rolę w tym procesie odegrały oczywiście, jak sugerował w przywołanym wcześniej artykule Marek Krajewski, przede wszystkim kasety wideo (także na przykład gadżety czy pisma erotyczne), a dokładniej dystrybuowane na nich filmy pornograficzne ${ }^{27}$. Mirosław Filiciak i Patryk Wasiak podają, że już w 1986 r. „Tygodnik Polski” donosił: 60 proc. kaset zatrzymywanych przez celników konfiskowanych jest za ,,niezgodność z polskimi normami moralnymi" ${ }^{28}$. Nie dziwi więc, iż na tę coraz bardziej rozerotyzowaną rzeczywistość zaczęło reagować również ówczesne kino. W rezultacie już od początku lat 80. polska publiczność mogła oglądać coraz więcej filmów zawierających śmiałe sceny nagości i wątki erotyczne, na przykład: Konopielkę (1981) Witolda Leszczyńskiego, Epitafium dla Barbary Radziwitłówny (1982) Janusza Majewskiego, Wilczyce (1982) i Powrót wilczycy (1990) Marka Piestraka, Kamienne tablice (1983) Ewy i Czesława Petelskich, Widziadło (1983) Marka Nowickiego, Seksmisję (1983) i Kingsajz (1987) Juliusza Machulskiego, Thais (1983) Ryszarda Bera, Alabame (1984) Ryszarda Rydzewskiego, Och, Karol 


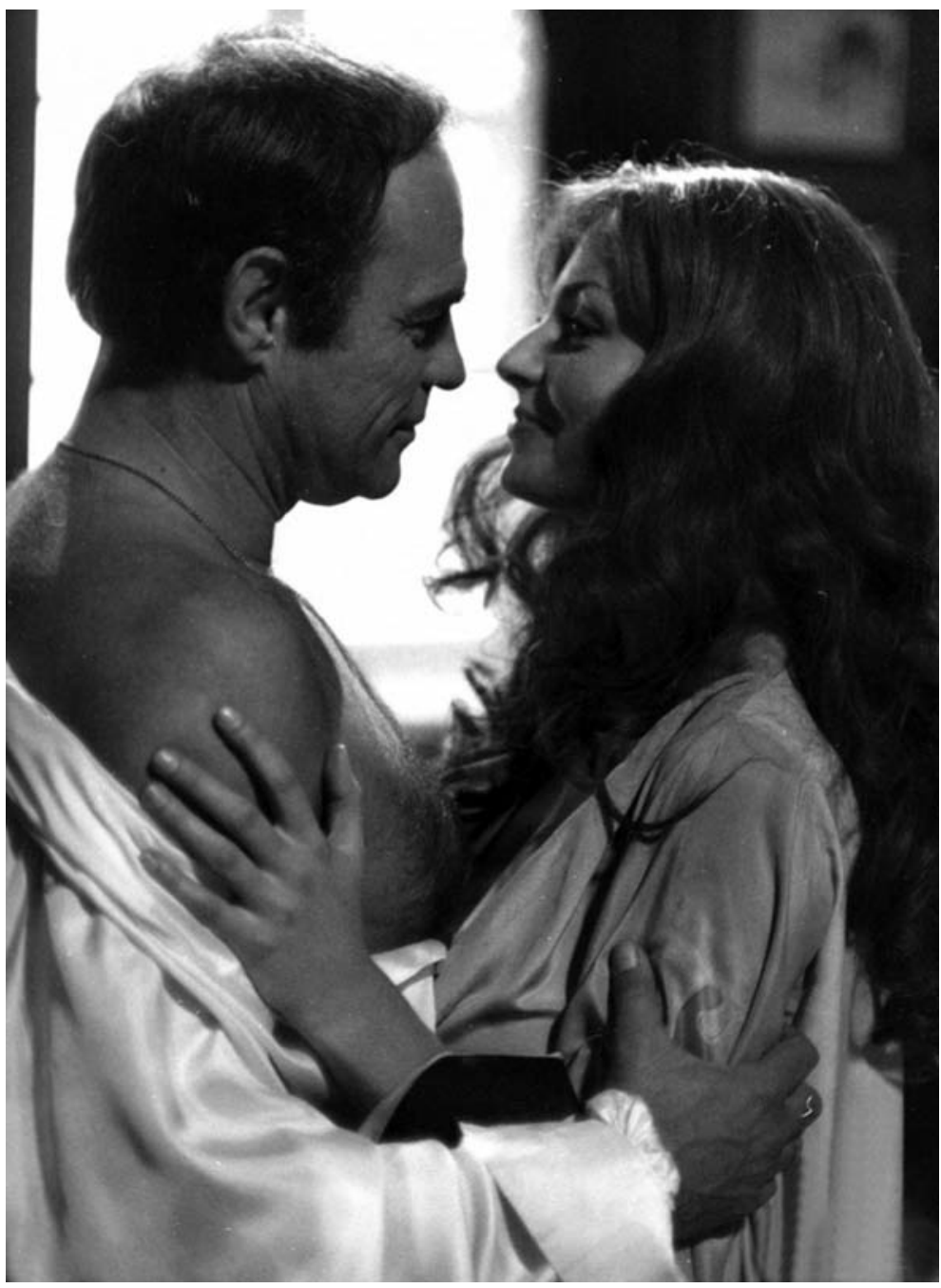

Widziadto, reż. Marek Nowicki (1983)

(1985) Romana Załuskiego, Medium (1985) Jacka Koprowicza, Lubię nietoperze (1985) Grzegorza Warchoła, Magnata (1985) Filipa Bajona, serial Tulipana (1986) Janusza Dymka i Andrzeja Swata, Łuk Erosa (1987) Jerzego Domaradzkiego, Życie wewnętrzne (1986) i Porno (1989) Marka Koterskiego, Sztukę kochania (1989) Jacka Bromskiego, Co lubia tygrysy (1989) Krzysztofa Nowaka czy In flagranti (1991) Wojciecha Biedronia.

Krzysztof Kornacki głównych przyczyn tej tendencji doszukiwał się w trzech równolegle toczących się procesach. Po pierwsze, lata 80 . to okres wyraźnego rozluźnienia, a nawet swego rodzaju liberalizacji sfery obyczajowej. Dlatego też, co oczywiste, zachodzące wówczas przemiany znajdowały swoje odbicie również w kinie ${ }^{29}$. Po drugie, spoglądając $z$ politycznego punktu widzenia, ekranowa erotyka stała się elementem szerszego zjawiska obecnego w polskim filmie - „,popu- 
laryzacji" kina (oficjalnej preferencji dla kina popularnego) ${ }^{30}$. W zgodzie z polityką kulturalną prowadzoną przez ówczesne władze po 13 grudnia $1981 \mathrm{r}$. w owej strategii chodziło przede wszystkim o przyciągnięcie do kin jak największej liczby widzów. Miało to doprowadzić do zneutralizowania nastrojów opozycyjnych (zasadniczym systemem wartości, wokół którego mogła się koncentrować społeczna aktywność, byt - o czym doskonale wiedziano - etos „, Solidarności” ${ }^{31}$ ). Należało więc tę opozycyjną atmosferę pilnie rozbroić, jak najprędzej doprowadzając do indywidualizacji zbiorowości ${ }^{32}$. Szeroko rozumiana rozrywka i kino rozrywkowe nadawały się do tego zadania. Po trzecie zaś, za erotyzacją ówczesnej produkcji filmowej stała też potrzeba jej komercjalizacji. Mówiąc w skrócie: już wtedy kino musiało (zacząć) na siebie zarabiać ${ }^{33}$, a przecież, w myśl zasady sex sells, nagość i erotyka temu sprzyjają.

Ten ostatni z wymienionych aspektów bodaj w największym stopniu przyczynił się do tego, jakie wątki podejmowane były najczęściej przez kino czasów przełomu i transformacji. Świadczyć o tym mogą zresztą już trzy tytuły inicjujące niejako ten trend, mające swoją premierę w 1984 r. - Seksmisja Juliusza Machulskiego, Widziadto Marka Nowickiego i Thais Ryszarda Bera, które nie tylko pokryly koszty rozpowszechniania, ale umożliwity też spłacenie ich produkcji, co w okresie PRL-u było ewenementem ${ }^{34}$. Były to przecież filmy rozrywkowe, a na dodatek ważną rolę w każdym z nich odgrywała tematyka erotyczna będąca wówczas gwarantem zwiększonego zainteresowania publiczności ${ }^{35}$. Warto wprawdzie dodać, że już w 1984 r., paradoksalnie, sukces tych utworów doprowadził do tego, że podczas reaktywowanego wtedy właśnie, po stanie wojennym, Festiwalu Filmów Fabularnych w Gdańsku, a także po jego zakończeniu pojawiły się negatywne opinie dotyczące rzekomej komercjalizacji filmu polskiego ${ }^{36}$. Narzekania te nie trwały jednak długo. Wkrótce z powrotem przerodziły się one bowiem, jak przekonywał Edward Zajiček, $w$ lament nad deficytem ${ }^{37}$, który nie był zresztą w czasach PRL-u niczym szczególnie zaskakującym. W rezultacie ówczesne kino coraz śmielej zaczęło sięgać po środki mogące przyczynić się do wzrostu frekwencji, a jego wyraźna komercjalizacja stała się faktem ${ }^{38}$.

Jednym z tego typu środków, o czym już wspominałem, była oczywiście rozlegle rozumiana erotyka. Nie oznacza to bynajmniej, że rodzima publiczność na ekranach kin mogła wówczas obejrzeć wiele filmów, w których w szczególnie pogłębiony sposób poruszona została problematyka erotyczna. Przeciwnie, Maria Kornatowska w słynnej książce Eros i film, wydanej w 1986 r., thumaczyła nawet, że kino polskie cierpi jej zdaniem na niedostatek erotycznej wrażliwości kompensowany ,odważna golizna”, najczęściej bez żadnych motywacji, tudzież rozmaitymi „momentami”, którymi szafuje hojnie gwoli przyciagnięcia widzów ${ }^{39}$. Warto wprawdzie zauważyć, że w słowach tych mimo wszystko jest jednak nieco przesady. Często bowiem, jak choćby w Bez końca (1984) Krzysztofa Kieślowskiego, wykorzystanie nagości nie byto przecież pozbawione podstaw, bywało wpisane $w$ fabutę i znaczenie filmu, jak również konwencję gatunkowa, niekiedy dopetniało także artystyczna wypowiedź ${ }^{40}$. Nie zmienia to faktu, że tematyka erotyczna rzeczywiście funkcjonowała wtedy w naszym kinie przede wszystkim w sposób pretekstowy, często przyjmując dosyć rubaszną, a nawet wręcz wulgarną postać. W większości przypadków wynikało to jednak bezpośrednio z autentycznych potrzeb samej publiczności, dobrze zaznajomionej już przecież chociażby z porno- 
grafią (której oglądanie, podobnie jak i innych filmów dystrybuowanych na kasetach wideo, bywało wówczas wyrazem posiadania własnego stylu życia i manifestacji indywidualności wobec socjalistycznego społeczeństwa ${ }^{41}$ ). W konsekwencji nasze kino zaludniło się wtedy wizerunkami nagich aktorek, by wymienić Grażynę Szapołowską, Katarzynę Figurę i Marię Probosz, a nagość i erotyka stały się chętnie wykorzystywaną strategią promocyjną. Nie tylko zresztą w samych filmach. Polscy widzowie coraz częściej mogli zetknąć się z tego typu obrazami również dzięki plakatom czy też fotosom prezentowanym w prasie oraz gablotach filmowych przed kinami, czasopismom ilustrowanym oraz prasie filmowej ${ }^{42}$, których podstawowym zadaniem było skutecznie przyciągnąć ich przed ekrany - jak słusznie przekonywał Piotr Zwierzchowski.

\section{Głosy ekspertów}

Rzeczywiście, jeśli uważnie przyjrzeć się ówczesnym protokołom z posiedzeń komisji kolaudacyjnych, kwestia mechanizmów kina rozrywkowego i w związku z tym oczekiwań polskiej publiczności była w nich często wyraźnie akcentowana. Jakie zatem treści zdaniem kolaudantów chciała oglądać rodzima publiczność? Potrzeby te przejrzyjście wyartykułował chociażby Bogumił Drozdowski podczas kolaudacji filmu Och, Karol w reżyserii Romana Załuskiego - polskiej komedii erotycznej z 1985 r. wg scenariusza Ilony Łepkowskiej. Jak mówił w czasie spotkania: Właściwie nie powinniśmy dyskutować na temat tego filmu, a powinniśmy podziękować reżyserowi za mile spędzony czas i pogratulować mu. Otrzymaliśmy bardzo zabawna komedię, z udziałem ładnych dziewcząt, które równie dobrze mogtyby brać udziat w konkursach piękności ${ }^{43}$. Przywołana opinia, skoncentrowana przede wszystkim na walorach rozrywkowych filmu i (męskiej) przyjemności wzrokowej (dość zresztą charakterystycznej dla naszej kinematografii), nie była odosobniona. Lekkość formy i nieczęsto dotąd wykorzystywaną w kinie polskim formułę gatunkową docenił również obecny na posiedzeniu Zygmunt Janik. Z sympatia i uznaniem odnoszę się do tego filmu, tym bardziej, że jest to pozycja rzadko spotykana w naszej kinematografii, bo rzadko kiedy mamy do czynienia z realizacjami w tym gatunku. Jest tu wiele zabawnych dowcipów, podanych z duża kultura, $i$ doskonale można się zorientować, że reżyser unikat tych sytuacji, które wykraczałyby poza granice kultury, ale mimo to udało mu się utrzymać zainteresowanie widzów ${ }^{44}$ - komentował.

Obecną w powyższej wypowiedzi troskę o dobry smak i, by tak rzec, moralność szerokiej publiczności jeszcze dobitniej usłyszeć można było podczas wcześniejszej, bo odbywającej się 27 grudnia 1983 r., dyskusji nad filmem Thais w reżyserii Ryszarda Bera. Uczestniczący w rozmowie Jerzy Jesionowski przekonywał więc: Ponieważ znam wiele opowiadań bachicznych, to warto powiedzieć, że te sceny nie budza instynktów seksualnych, a więc nie można posadzać reżysera o to, że będzie chciat on podniecać młodych ludzi przychodzacych do kina. Na pewno takie sceny nikogo nie będa gorszyty ${ }^{45}$. Na temat wielu ukazanych na ekranie wątków erotycznych wypowiedział się także biorący udział w posiedzeniu Jerzy Bossak: Broniłbym się przed (...) określeniem, że jest to film hollywoodzki, a wymieniony przez mego przedmówcę „Kaligula” jest filmem po prostu niemadrym, budzacym niesmak, przekraczajacym granicę tego, co chcemy oglądać na ekranach. Tutaj te 
sprawy zostały zademonstrowane $z$ dobrym smakiem ${ }^{46}$. Wyraźnie więc widać, że o ile tematyka erotyczna nie należała już do sfery tabu, a szeroka publiczność była z nią przecież dosyć dobrze zaznajomiona, o tyle w dalszym ciągu kwestią sporną była jej rzeczywista funkcja i sposób przedstawiania w filmach. Choć w przypadku Thais warto również zadać sobie pytanie, na ile powyższe słowa kolaudantów nie były przede wszystkim grą pozorów. Zobrazowane w tym filmie sceny erotyczne, choć nie były oczywiście pornografią, niewiele miały bowiem wspólnego z postulowanym artyzmem czy finezyjnością formy.

Schyłek dekady nie pozostawił już jednak nawet najmniejszych wątpliwości w kwestii tego, jaką rolę powinny odgrywać w realizowanych wtedy filmach mało wysublimowane wątki erotyczne. Podczas kolaudacji filmu Co lubia tygrysy w reżyserii Krzysztofa Nowaka, odbywającej się 20 grudnia 1988 r., do kwestii tej odniósł się przewodniczący komisji - Jerzy Schönborn: Na pewno ten rodzaj humoru nie jest specjalnie subtelny, ale jeżeli chcemy trafić do szerokiego widza, to nie możemy nastawić się na subtelne dowcipy, bo one mogtyby stanowić przeszkodę $w$ odbiorze filmu, natomiast mówimy o filmie popularnym, na jaki jest zapotrzebowanie, i jestem przekonany, że na ten film pójdzie spora ilość widzów. Sądze, $\dot{z}$ e reżyser będzie miat tantiemy, a publiczność frajdę ${ }^{47}$. W bardzo podobnym tonie na temat preferencji ówczesnej widowni wypowiedział się również Stanisław Trepczyński w czasie kolaudacji Sztuki kochania w reżyserii Jacka Bromskiego: Wartość tego filmu polega na tym, że nie jest to tylko film dla młodzieży, ale równiez $i$ dla dorostych. Jest $w$ filmie poruszony temat doznań erotycznych, a sa to sprawy nie tylko ważne dla młodzieży. (...) Jestem pełen uznania dla reżysera i uważam, że zrobit świetny film ${ }^{48}$. Warto wprawdzie zaznaczyć, że dla odmiany podczas posiedzenia komisji kolaudacyjnej trzeciej głośnej produkcji erotycznej końca lat 80., czyli filmu Porno w reżyserii Marka Koterskiego, licznie obecne w nim wątki i sceny erotyczne nie spotkały się już z aż tak jednoznacznym entuzjazmem i przychylnością kolaudantów (Ja mogę powiedzieć, że jako starszy pan bardzo lubię pornografie, no ale zgodnie z tym, co napisat o niej pewien inny starszy pan Boy - lubię ja w eleganckim wydaniu. Ta pornografia wyglada mi na nieelegancka, co gorsza, rzadko się zdarza, żebym tak się wynudzit na filmie ${ }^{49}$ tłumaczył m.in. Kazimierz Koźniewski). Niemniej komercyjny sukces, jaki w bardzo szybkim tempie udało się osiągnąć temu tytułowi, niewątpliwie świadczy o ogromnej popularności, z jaką tego typu treści spotykały się wśród ówczesnych widzów ${ }^{50}$.

Zdecydowanie mniej przychylne głosy dotyczące niezbyt wysokiej jakości rodzimej erotyki, o czym świadczyć może już przywołana na wstępie wypowiedź Tadeusza Sobolewskiego, dużo częściej można było usłyszeć w ówczesnych recenzjach i tekstach krytycznych. Na naszych ekranach króluje obecnie niepodzielnie polska komedia Romana Załuskiego (reżyseria) i Ilony Łepkowskiej (scenariusz) „Och, Karol!”. Niepodzielnie, albowiem przed kasami ustawiaja się kolejki, co $w$ czasach udostępnienia oficjalnie chętnym z kaset video szlagierów w rodzaju „Caliguli” uznać należy za zjawisko godne niemal UFO. „Och, Karol!” nie reprezentuje bowiem żadnego poziomu, jeżeli w ogóle na znalezienie $w$ przypadku tego typu komedii istnieje możliwość określenia jakichś granic estetycznych i intelektualnych ${ }^{51}$ - grzmiał więc na przykład Tomasz Śrutkowski na łamach „Gazety Olsztyńskiej”. Taki rodzaj retoryki charakteryzował recepcję polskich filmów ero- 


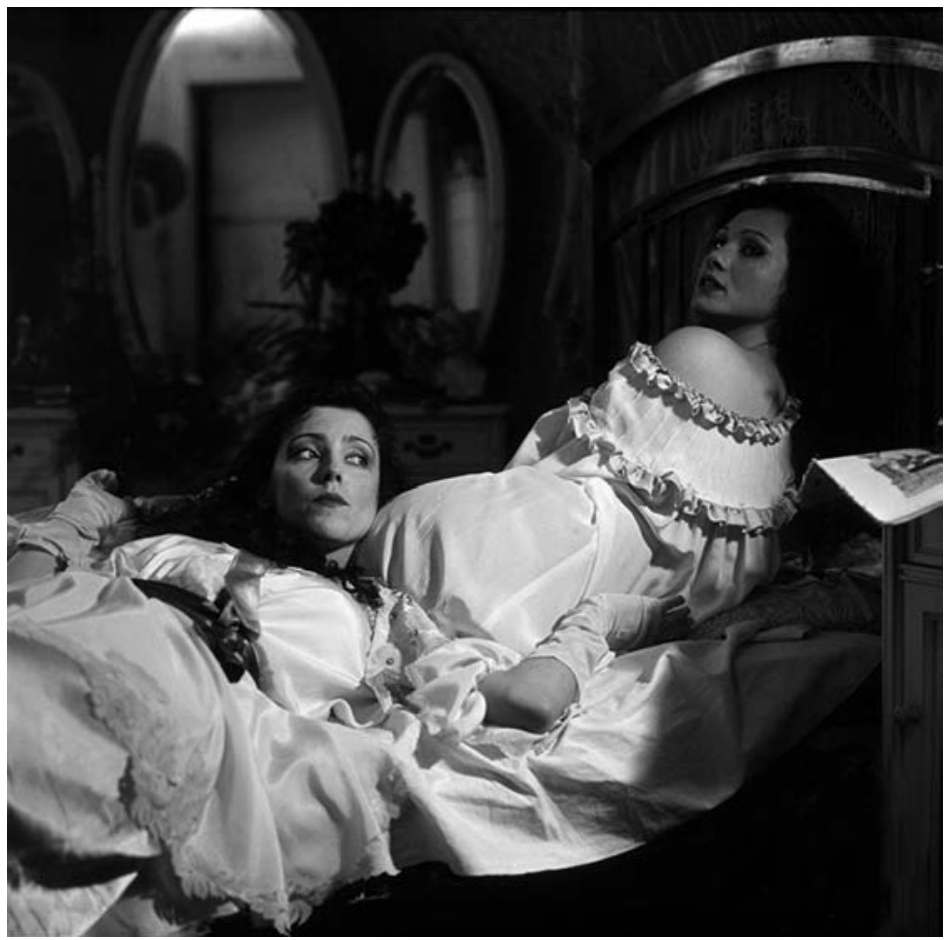

Łuk Erosa, reż. Jerzy Domaradzki (1987)

tycznych lub zawierających wątki erotyczne w prasie tego okresu. Mało entuzjastyczne głosy krytyczne bardzo często były bowiem bezpośrednim skutkiem problematycznego podejścia do kina popularnego, a także, szerzej, do kultury popularnej. To nieustająco określało moim zdaniem, przynajmniej od lat 60., rodzimy dyskurs ekspercki na temat erotyki ${ }^{52}$. Choć niekiedy również, mówiąc żartem, negatywne komentarze dotyczące niezbyt udanych polskich filmów erotycznych wynikały także z zupełnie innego rodzaju przesłanek, jak m.in. w przypadku dziennikarza „Kuriera Lubelskiego”, który publicznie ubolewał w swoim artykule: Jeszcze raz się okazało, że w tej materii niezastapiona jest Grażyna Szapołowska, akurat w tym filmie nieobecna. Szkoda. To westchnienie męskiej części widowni, w tym niżej podpisanego. Natomiast niektóre panie nie moga się nadziwić, co takiego jest $w$ Janie Piechocińskim, który na supermana raczej nie wygląda, a reżyser każe mu dosłownie „,pożerać” każda napotkana kobietę ${ }^{53}$.

Przywołane opinie dotyczące nie tylko dyskusyjnego poziomu ,erotyki po polsku" ${ }^{54}$, ale również oczekiwań ówczesnej krytyki względem kina rozrywkowego nie należały oczywiście, jak już wcześniej wspomniałem, do rzadkości. Doświadczenia polskiego kina w prezentowaniu wątków seksu i erotyki nie sa najlepsze. Nastawiony głównie na epatowanie widza, wtracany dla podniesienia komercjalnych walorów obrazu - erotyzm naszych filmów jest na ogót prymitywny, obdarty z głębszych psychologicznych treści, obliczony na dostarczenie mało wymagajacemu widzowi dawki atrakcyjnych wrażen ${ }^{55}$ - argumentował zatem Marek Sadowski w „Rzeczpospolitej”. Janusz Zatorski w „Kierunkach” tłumaczył: zalecajacy 
się do widza gotymi plakatami twórca traktuje swego odbiorce jak ponurego, śliniacego się na widok kawałka uda erotomana, co jest fatalnym błędem, by nie nazwać tego glupotą. Otóż erotomani, tudzież ludzie, powiedzmy oględnie, szczególnie zainteresowani seksem ekranowym, maja dziś do dyspozycji setki kaset wideo i po prostu nie interesuje ich nagość kilku dyżurnych aktoreczek od tych spraw, bo ogladaja , Kaligulę”, kilkadziesiąt odcinków „Emmanuelle” i hardporno. Proszę więc przestać traktować widzów jak kretynów i robić filmy także o miłości i erotyzmie dla normalnych ludzi ${ }^{56}$. Temat ,porno” przestat być tabu. Mało tego, dla podreperowania państwowej kasy sprowadza się z Zachodu filmy nieraz wyłacznie ze względu na ,,momenty”. Te filmy, niezależnie od tego, co pisze o nich krytyka, funkcjonują na zasadzie „,porno”, choć nimi nie sa (patrz: „, Betty” Beneixa). „Porno” weszło do kultury masowej na zasadzie najtańszego pocieszenia - ono najprędzej odciaga wzrok od rzeczywistości, na która często nie ma się ochoty patrzeć. (...) czym jest dla nas pornografia? Na pewno czymś innym niż dla bogatych społeczeństw. Tam jest to rozrywka dla najbiedniejszych. Myślę, że nasza krajowa ekscytacja „porno” może być jednym z symptomów ubóstwa. Pornografia wynalazek stary jak świat, stużacy do budzenia i rozładowywania pożądań - ma u nas specjalny smak, jest dobrem zastępczym ${ }^{57}$ - ubolewał Tadeusz Sobolewski na łamach „Filmu”. Dość zresztą powiedzieć, że powyższe opinie to naprawdę tylko niewielki w istocie wyimek głosów krytycznych, jakie z wielką siłą zaczęły się pojawiać w prasie. Tego typu negatywnych komentarzy można było bowiem wtedy przeczytać znacznie więcej.

\section{Co z tą nagością?}

Przywołana na początku wypowiedź Tadeusza Sobolewskiego bodaj w najpełniejszy sposób ujawnia zresztą istotę funkcjonowania szeroko definiowanej nagości i treści erotycznych w rzeczywistości przełomu. Wprawdzie w słowach krytyka słychać jeszcze sporą dozę dezaprobaty, erotyka bowiem nie spotykała się wówczas w naszym kraju z jednoznacznym czy jednorodnym odbiorem, niemniej już na ich podstawie można dostrzec, w jakich kategoriach była ona postrzegana przez Polaków. Tego rodzaju obrazy były przecież s ta m tąd i już sam ten fakt mógł wystarczająco świadczyć o ich wartości. Warto zresztą dodać, że wspomniana ambiwalencja w odbiorze tego-co-erotyczne wynikała, co swoją drogą oczywiste, z bardzo różnych przesłanek. Z jednej strony, zwłaszcza w dyskursie krytycznym, nadmiarowa obecność scen erotycznych w kinie polskim okresu przełomu schlebiała komercyjnym gustom szerokiej publiczności. Natomiast z drugiej - zainteresowanie tematyką erotyczną, manifestowane na przykład chodzeniem do kina na filmy zawierające tego typu treści ( $\mathrm{z}$ reguły filmy nie najlepsze), było odbierane przez widzów jako swego rodzaju emanacja nowoczesności (a nawet zachodniości), świadectwo zmieniających się postaw i ewoluujących norm obyczajowych. Choć bywało też po prostu sposobem spędzania czasu, zwyczajną rozrywką.

Owa różnorodność, złożoność, a także, by tak rzec, pewne rozproszenie refleksji dotyczących erotyki nie oznacza, że zagadnienie to nie było w tamtym okresie na swój sposób konstytutywne, powszechne i tożsame. Przeciwnie, erotyka stanowiła niezwykle ważny punkt odniesienia dla tamtych czasów, niezależnie zresztą od fali negatywnej krytyki, jaka regularnie spadała na nią w prasie, czy od nad- 
miarowej w istocie skali wykorzystywania tego typu wątków w strategiach komercyjnych, często zachowawczych i z reguły niezbyt pogłębionych. Paradoksalnie jednak, jak pisała Izabela Kalinowska, polityka kulturalna ostatniej dekady PRL-u, a szczególnie przyzwolenie na seks, wywołało skutek przeciwny do zamierzonego: skomercjalizowana cielesność pojawiająca się na ekranach kin i telewizorów $w$ trakcie lat 80. przygotowala grunt pod mająca wkrótce nastapić zmianę systemu, przekształcając stopniowo pracujacy lud miast $i$ wsi w konsumentów kultury popularnej ${ }^{58}$.

KAROL JACHYMEK

${ }^{1}$ T. Sobolewski, Porno, „Gazeta Wyborcza” 1990, nr 25. Cyt. za: K. Kornacki, Naga wtadza. Polskie kino erotyczne (schylkowego PRL-u), „Studia Filmoznawcze” 2008, nr 29, s. 213.

${ }^{2}$ Zob. A. Banach, Erotyzm po polsku, „Kino” 1967 , nr 9, s. 2-11.

${ }^{3}$ Tamże, s. 3 .

${ }^{4}$ Z. Lew-Starowicz, Erotyzm, w: tegoż, Encyklopedia erotyki, Wydawnictwo Muza S.A., Warszawa 2004, s. 181.

${ }^{5}$ Tamże.

${ }^{6}$ Tamże.

${ }^{7}$ Zob. tamże.

${ }^{8}$ Stankusz, Seks po polsku, ,Kino” 1986, nr 1, s. 16. Cyt. za: K. Kornacki, Naga władza... dz. cyt., s. 204.

${ }_{9}$ Zob. B. Łaciak, Obyczajowość polska czasu transformacji, czyli wojna postu z karnawatem, Wydawnictwo Trio, Warszawa 2007.

${ }^{10}$ Por. K. Jachymek, Danuta Lato. Ekscesywne ciato przełomu, „Kultura Popularna” 2019, nr 1 (w druku).

${ }^{11}$ M. Szcześniak, Normy widzialności. Tożsamość w czasach transformacji, Fundacja Bęc Zmiana, Instytut Kultury Polskiej UW, Warszawa 2016, s. 15.

${ }^{12}$ Tamże.

${ }^{13}$ Tamże, s. 16.

${ }^{14}$ Tamże.

${ }^{15}$ Zob. S. Jagielski, Kino polskie w czasach transformacji, w: Historia kina. Tom 4. Kino końca wieku, red. T. Lubelski, I. Sowińska, R. Syska, Towarzystwo Autorów i Wydawców Prac Naukowych Universitas, Kraków 2019, s. 1010-1011.

${ }^{16}$ M. Krajewski, Koniec lat 80-tych. Rewolucja wyobraźni, w: M. Forecki, I love Poland, Związek Polskich Artystów Fotografików. Okręg Wielkopolski, Poznań 2009. Zob. też: https://www.academia.edu/2540689/Koniec_la
t_80-tych._Rewolucja_wyobraźni (dostęp: 22.04.2019).

${ }^{17}$ Tamże.

18 Tamże.

${ }^{19}$ Tamże.

${ }^{20}$ Tamże.

${ }^{21}$ Zob. B. McNair, Seks, demokratyzacja pożadania i media, czyli kultura obnażania, thum. E. Klekot, Wydawnictwo Muza S.A., Warszawa 2004, s. 127-178.

${ }^{22}$ Zob. tamże, s. 128-130; L. Nijakowski, Pornografia. Historia, znaczenia, gatunki, Wydawnictwo Iskry, Warszawa 2010, s. 199-202; L. Williams, Hard core. Władza, przyjemność $i$, szaleństwo widzialności”, tłum. J. Burzyńska, I. Hansz, M. Wojtyna, słowo/obraz terytoria, Gdańsk 2010, s. 120-128; L. Williams, Seks na ekranie, thum. M. Wojtyna, słowo/obraz terytoria, Gdańsk 2013, s. 131-175.

${ }^{23}$ B. McNair, Seks, demokratyzacja pożądania ... dz. cyt., s. 127-128.

${ }^{24}$ Tamże, s. 146.

${ }^{25}$ Więcej na jej temat piszę w artykule: K. Jachymek, Danuta Lato... dz. cyt.

${ }^{26}$ Por. K. Jachymek, A Train to Hollywood: Porno-Chic in the Polish Cinema of the Late $1980 s$, „European Journal of American Studies" 2018, nr 13-3, https://journals.openedition.org/ejas/13625 (dostęp: 23.04.2019).

${ }^{27} \mathrm{O}$ powszechności pornografii w okresie przełomu, również wśród młodzieży, można przeczytać m.in. w: A. Kościańska, W. Sokoluk, Instruktaż nadmierny. Historia pewnej przygody seksualnej, Wydawnictwo Czarne, Wołowiec 2018, s. 143-148.

${ }^{28}$ M. Filiciak, P. Wasiak, Wypożyczalnia rewolucji, „Polityka” 2013, nr 22, s. 90.

${ }^{29}$ Więcej na ten temat piszę w: K. Jachymek, Seks w kinie polskim okresu PRL, „Pleograf. Kwartalnik Akademii Polskiego Filmu” 2018, nr 1, http://www.akademiapolskiegofilmu.pl/pl/hi- 
storia-polskiego-filmu/artykuly/seks-wkinie-polskim-okresu-prl-wprowadzenie/626 (dostęp: 23.04.2019).

${ }^{30}$ K. Kornacki, Naga władza... dz. cyt., s. 202.

${ }^{31}$ Tamże.

${ }^{32}$ Tamże.

${ }^{33}$ Zob. tamże, s. 201-202.

${ }^{34}$ S. Jagielski, Kino polskie w czasach transformacji, dz. cyt., s. 985.

${ }^{35}$ Choć Krzysztof Kornacki tłumaczył w swoim artykule, że po seansie jednego z tych filmów niektórzy widzowie byli dosyć rozczarowani. „Jestem rozczarowany, spodziewatem się naprawdę seksu. Tytut wprowadzat w błą", jak thumaczyt kapral czynnej stużby wojskowej, zapytany po projekcji ,, Seksmisji”, przed redakcję "Tygodnika Kulturalnego". Zob. K. Kornacki, Naga wtadza... dz. cyt., s. 195. Autor powołuje się na: Widzowie o „Seksmisji”, „Tygodnik Kulturalny” 1984, nr 25.

${ }^{36}$ E. Zajiček, Poza ekranem. Polska kinematografia $w$ latach 1896-2005, Stowarzyszenie Filmowców Polskich, Studio Filmowe Montevideo, Warszawa 2009, s. 284.

${ }^{37}$ Tamże.

${ }^{38}$ Więcej na ten temat można również przeczytać m.in. w: T. Lubelski, Historia kina polskiego 1895-2014, Towarzystwo Autorów i Wydawców Prac Naukowych Universitas, Kraków 2015, s. 547-557; M. Adamczak, Globalne Hollywood, filmowa Europa i polskie kino po 1989 roku. Przeobrażenia kultury audiowizualnej przełomu stuleci, słowo/obraz terytoria, Gdańsk 2010.

${ }^{39}$ M. Kornatowska, Eros i film, Krajowa Agencja Wydawnicza, Łódź 1986, s. 22-23.

${ }^{40}$ P. Zwierzchowski, Nagość jako strategia promocyjna kina polskiego lat 80., ,Images. The International Journal of European Film, Performing Arts and Audiovisual Communication" 2018, t. 23, nr 32, s. 175.

${ }^{41}$ P. Wasiak, „Zwoje muskułów monstrualnych rozmiarów i dużo nagiego ciała”. Kultura popularna, nowe technologie medialne i legitymizacja socjalistycznego projektu kulturowego, „Kultura Popularna” 2014, nr 2, s. 76.

${ }^{42}$ P. Zwierzchowski, Nagość jako strategia promocyjna kina polskiego lat 80., dz. cyt., s. 173.

${ }^{43}$ Stenogram z posiedzenia Komisji Kolaudacyjnej Filmów Fabularnych $w$ dniu 7 sierpnia 1985 r. Na porządku dziennym: omówienie filmu pt. „Och, Karol!” zrealizowanego przez reż. Romana Załuskiego w Zespole „Oko”, Archiwum Filmoteki Narodowej - Instytutu Audiowizualnego (AFINA), sygn. A-344, poz. 407, k. 1.
${ }^{44}$ Tamże, k. 5.

${ }^{45}$ Stenogram z posiedzenia Komisji Kolaudacyjnej Filmów Fabularnych $w$ dniu 27 grudnia 1983 r. Na porzadku dziennym: omówienie filmu pt. „,Thais” zrealizowanego przez reż. R. Bera w Zespole „Silesia”, AFINA, sygn. A-344, poz. 351, k. 2-3.

${ }^{46}$ Tamże, k. 6-7.

${ }^{47}$ Stenogram z posiedzenia Komisji Kolaudacyjnej Filmów Fabularnych $w$ dniu 20 grudnia 1988 r. Na porządku dziennym: omówienie filmu pt. „Co lubia tygrysy” - zrealizowanego przez reż. Krzysztofa Nowaka $w$ Zespole „Oko”, AFINA, sygn. A-344, poz. 574, k. 5.

${ }^{48}$ Stenogram z posiedzenia Komisji Kolaudacyjnej Filmów Fabularnych $w$ dniu 1 grudnia 1988 roku. Na porządku dziennym: omówienie filmu pt. „Sztuka kochania” zrealizowanego przez reż. Jacka Bromskiego w Zespole ,,Zebra”, AFINA, sygn. A-344, poz. 570, k. 1-2.

${ }^{49}$ Stenogram z posiedzenia Komisji Kolaudacyjnej Filmów Fabularnych z dnia 10 marca 1989 r. Na porzadku dziennym: omówienie filmu pt. „Porno” zrealizowanego przez reżysera Marka Koterskiego $w$ zespole filmowym „Zebra”, AFINA, sygn. A-344, poz. 577, k. 1.

${ }^{50}$ Zob. K. Kornacki, Naga władza. Polskie kino erotyczne (schytkowego PRL-u), dz. cyt., s. 201-202. Warto zresztą podkreślić, że przyciągnięcie do kin jak największej liczby widzów było jednym z podstawowych celów samego Marka Koterskiego.

${ }^{51}$ T. Śrutkowski, Makatka ,, Och, Karol”, , ,Gazeta Olsztyńska" 1985, nr 285.

52 Więcej na ten temat piszę w książce: K. Jachymek, Film - ciało - historia. Kino polskie lat sześćdziesiatych, Gdańsk 2016, s. 198.

${ }^{53}$ żak, Szkoda, że zabrakło Szapołowskiej, „Kurier Lubelski” 1985, nr 215.

${ }^{54}$ Nawiązuję tutaj oczywiście do przywołanego już wcześniej artykułu autorstwa Andrzeja Banacha zatytułowanego Erotyzm po polsku.

${ }_{55}$ M. Sadowski, Och, kaso... „Rzeczpospolita” 1985, nr 263.

56 J. Zatorski, Tygrysy i Pasikoniki, „Kierunki” 1989, nr 27, s. 15 .

${ }^{57}$ T. Sobolewski, Momenty, „Film” 1989, nr 1, s. 6.

${ }^{58}$ I. Kalinowska, Seks, polityka i koniec PRL-u: o cielesności $w$ polskim kinie lat osiemdziesiątych, w: Ciało i seksualność w kinie polskim, red. S. Jagielski, A. Morstin-Popławska, Wydawnictwo Uniwersytetu Jagiellońskiego, Kraków 2009, s. 78. 